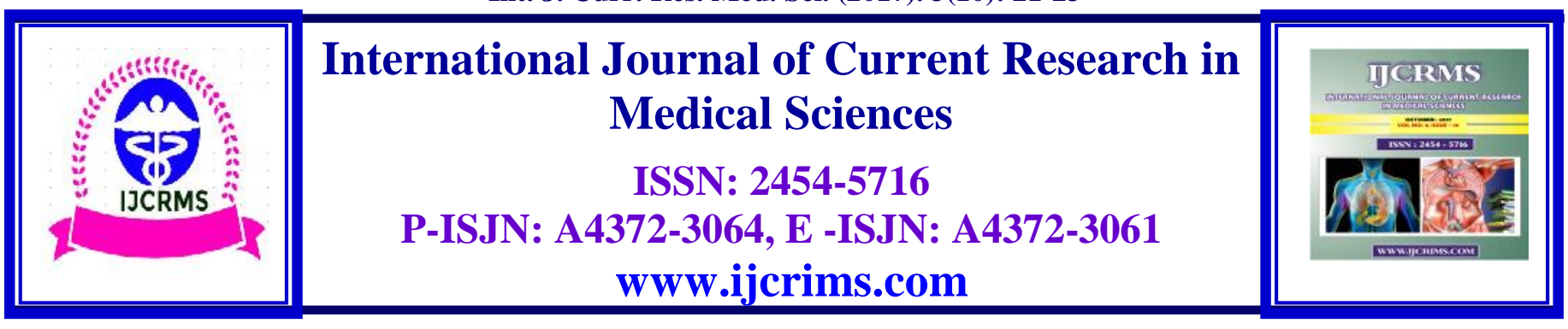

Case Report

Volume 3, Issue 10 -2017

DOI: http://dx.doi.org/10.22192/ijcrms.2017.03.10.005

\title{
Parameatal urethral cyst- A rare case presentation and Review of literature
}

* SP Hans, ** Anand Dutta, ** Sahil Mashal, ** Devika, ** Gaurav Sharma *Professor, **Junior Resident, Department of General Surgery, Govt. Medical College \& Guru Nanak Dev Hospital, Amritsar, India, 143001

Corresponding author: Dr. Anand Dutta, Junior Resident, Dept. of General Surgery, Govt. Medical College \& Guru Nanak Dev Hospital, Amritsar, India, 143001

E- mail:drananddutta@gmail.com

\section{Abstract}

Cyst formation in parameatal area of urethra is a very rare congenital anomaly. It was first reported in two males in 1956 by Thanpson and Lantin. Approximately 60 cases have been reported till now. Maximum number of cases have been reported from Japan, but few cases were found in India. Herein, we are reporting a case of papameatal urethral cyst in 25 year old male. The Cyst was completely excised for management and prevention of recurrence.

Keywords: Parameatal Cyst, Urethral Cyst

\section{Case Report}

A 25 Year old male presented in surgery department with a swelling over urethral meatus. The swelling had been present since his childhood, which was very slowly increasing in size. There were no urinary symptoms, polyuria or spraying of urinary stream.

\section{On Examination:}

A Cystic mass of about $1 \mathrm{~cm}$ in diameter was found at external urethral meatus. (Figure-1) It had shining lining, smooth and was covered with mucosa. There was no history of trauma. Blood Picture, Complete urine analysis were normal.
His viral markers like $\mathrm{HIV}, \mathrm{HBsAg}, \mathrm{HCV}$ were nonreactive. His fasting blood sugar was 110 $\mathrm{mg} / \mathrm{dl}$.

The Cyst was excised under spinal anaesthesia, taking care to remove all epithelial lining, Histological examination showed squamous epithelium showing fibro-collagenous tissue within the centre, the lumen is lined by transitional epithelium. (Figure-2) 


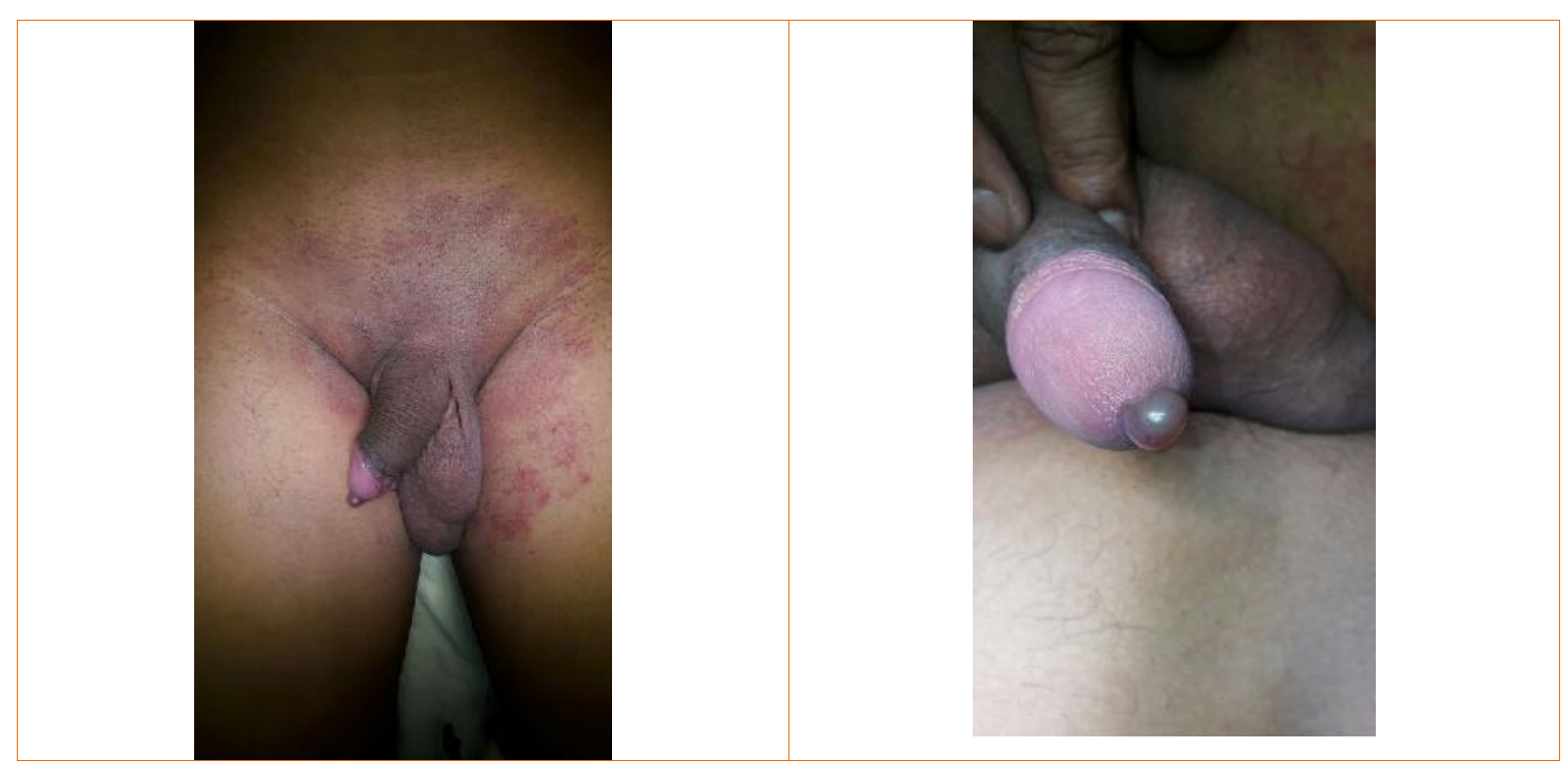

Figure 1: Clinical Photograph of parameatal Urethral cyst of the glans penis
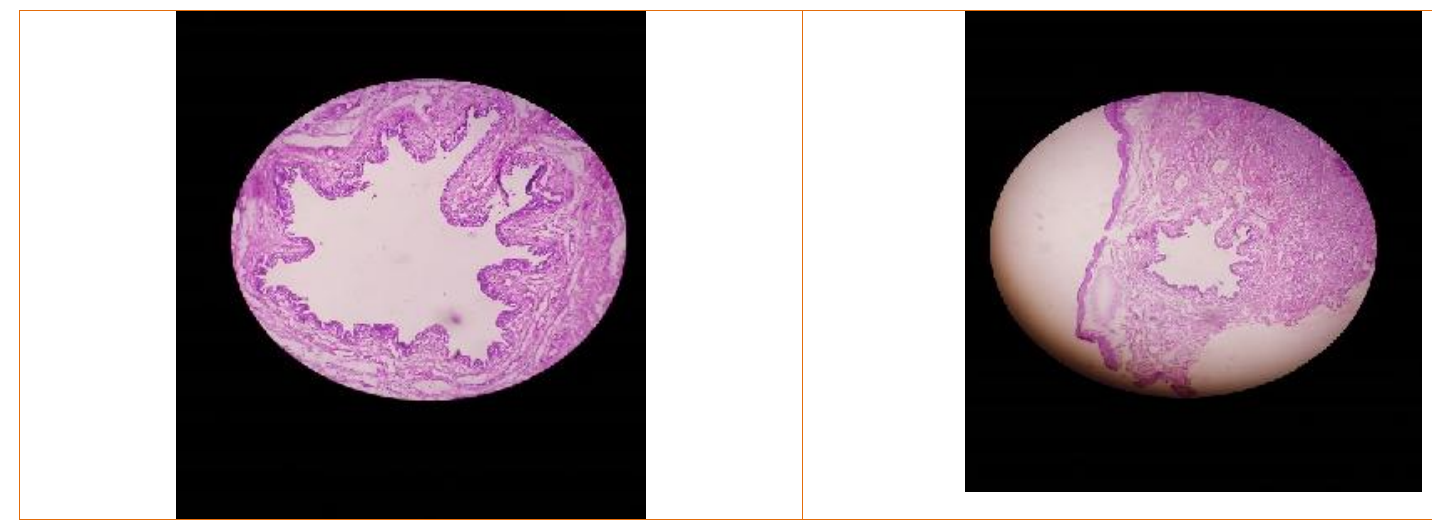

Figure 2: section showing stratified squamous epithelium showing fibro-collogenous tissue within the centre is seen a luman lining by transitional epithelium.

\section{Discussion}

Parameatal Urethral Cysts are very rare cyst occurring in males and very rarely can occur in females. The case was first reported by Thompson $\&$ Lantin $^{1}$ in 1956. And approximately 60 cases have been reported since then. The pathogenesis of the Cyst is still under study. Thompson and Lautin stated that parameatal urethral cyst occurs in process of delamination or separation of foreskin from glans penis, while Shiraki ${ }^{2}$, Oka et al. $^{3}$ and Yoshida et al. $^{4}$ believed that they are caused by occlusion of paraurethral ducts. Hills et $\mathrm{al}^{5}$ believed that obstruction can be due to infection. Soyer et $\mathrm{al}^{6}$ reported two cases of newborn in whom paraurethral cysts which were associated with vaginal bleeding \& breast enlargement were seen, showed possibility of role of estrogen.
The origin of parameatal urethral cysts from accessory male sex glands in the penile urethra was demonstrated by detection of prostaticspecific antigen (PSA) in cells of these cysts with the help of immunohistochemistry ${ }^{7}$. In our case, a parameatal duct obstruction could have been a possible aetiology.

The cysts are usually small of about $1 \mathrm{~cm}$ in diameter. They occur on the external urethral meatus and at times, they can be bilateral. They may be congenital or they may appear spontaneously ${ }^{4}$. In our case, the lesion was about $0.8 \mathrm{~cm}$ in diameter and it had appeared spontaneously. Diagnosis is incidental when cysts are asymptomatic. However, sometimes, they may cause urinary retention, painful micturition 
and sexual intercourse ${ }^{8}$, poor cosmesis, and distortion of urinary stream. When the cysts are traumatized; they may bleed, rupture or become infected.

The treatment of choice for such cysts is complex excision; however, needle aspiration, simple decapping, and marsupialization have also been reported but recurrences are common with these methods ${ }^{2}$. Histological examinations have shown that these cysts are lined by different types of epithelium like columnar, transitional, cuboidal or squamous. The lining epithelium actually varies according to the segmental origin of the urethra of the lesion. In present case, the cyst wall was lined by tall columnar epithelium.

\section{Conclusion}

A parameatal urethral cysts is benign, usually asymptomatic condition that may contain a variety of epithelial types. A physical examination is sufficient to make a diagnosis and complete surgical excision is necessary to obtain good cosmetic result without recurrence.

\section{Source of funding: Nil}

Conflict of interest: None declared

\section{References}

1. Thompson IM, Lantin PM. Parameatal cyst of the glans penis. J Urol. 1956;76:753-55.

2. Shiraki IW. Parameatal cysts of the glans penis: a report of 9 cases. J Urol. 1975;114:544-48.

3. Oka M, Nakashima K, Sakoda R. Congenital urethral cyst in the male. $\mathrm{Br} \mathrm{J}$ Urol. 1978;50:340-41.

4. Yoshida K, Nakame Y, Negishi T. Parameatal urethral cysts. Urology. 1985;36:490-91.

5. Hill JT, Ashken M. Handley. Parameatal urethral cyst: a review of six cases. Br J Urol. 1977;49:323-25.

6. Soyer T, Aydemir E, Atmaca E. Paraurethral cysts in female newborns: role of maternal estrogenes. J Ped Adol Gyn. 2007;20:249-51.

7. Ichiyanagi $\mathrm{N}$, Shibata $\mathrm{T}$, Matsumura $\mathrm{T}$, Ishimoru H, Sakai I. Immunohistochemical identification of prostatic-specific antigen in parameatal urethral cysts of the glans penis. Br J Urol. 1998;81:170-71.

8. Nerli RB, Patil S, Hiremath MB. Parameatal Urethral Cysts Presenting with painful Intercourse. Med Surg Urol. 2012;1:104.

\begin{tabular}{|c|l|}
\hline \multicolumn{2}{|c|}{ Access this Article in Online } \\
\hline & Website: \\
\hline & www.ijcrims.com \\
\hline Quick Response Code & Subject: \\
\hline
\end{tabular}

How to cite this article:

SP Hans, Anand Dutta, Sahil Mashal, Devika, Gaurav Sharma. (2017). Parameatal urethral cyst- A rare case presentation and Review of literature. Int. J. Curr. Res. Med. Sci. 3(10): 21-23.

DOI: http://dx.doi.org/10.22192/ijcrms.2017.03.10.005 